\title{
The Relationship of Environmental Sanitation and Family Attitudes with Events of Dengue Hemorrhagic Fever (DHF) in Working Areas UPTD Public Health Centre Bendo Kediri District
}

\author{
Ahmad Wasis Setyadi ${ }^{1}$, Astri \\ Yunita $^{2}$, Nanang Muhibuddin ${ }^{3}$ \\ ${ }^{1}$ Komunitas, Keperawatan, \\ STIKes Bhakti Mulia \\ ${ }^{2}$ Komunitas, Kebidanan, STIKes \\ Bhakti Mulia \\ ${ }^{3}$ Komunitas, Keperawatan, \\ STIKes Bhakti Mulia \\ Email: \\ ahmadwasisw@gmail.com
}

Received : March 27th 2021

Accepted : April 29 2021

Published : May 20 2021

\begin{abstract}
Background: Dengue Hemorrhagic Fever (DHF) is still a public health problem in Indonesia. The increase in dengue cases every year is related to poor environmental sanitation. The purpose of this study was to determine the relationship of environmental sanitation and family attitudes with the incidence of dengue in the working area of UPTD Public Health Centre Bendo, Kediri Regency, 2019.

Methods: The design was correlational analytic research with cross sectional approach. The population of the entire community working area UPTD Public Health Centre Bendo District of Kediri 30 families were detected dengue with a sample of 30 respondents taken a total sampling. The independent variable was environmental sanitation and attitude, the dependent variable was dengue collected by questionnaire and checklist and analyzed by Mc Nemar test and Linear Regression.

Result: To the $\mathrm{p}=<0.05$ then $\mathrm{H} 0$ is rejected and $\mathrm{p}=>0.05$ then $\mathrm{HO}$ is accepted. Environmental sanitation with the incidence of DHF $(p=0.031)$. Family attitudes with the incidence of DHF $(\mathrm{p}=0.039)$. Environmental sanitation and family attitudes with the incidence of DHF in the Work Area of UPTD Public Health Centre Bendo, Kediri Regency in 2019 ( $p=0.110)$.

Conclusion: there was a relationship between environmental sanitation and the incidence of DHF, there was a relationship between family attitudes and the incidence of DHF and there was no relationship between environmental sanitation and family attitudes with the incidence of DHF. So that people are more concerned about environmental sanitation to reduce the occurrence of dengue fever as a manifestation of the movement of one house 1 cadre of jumantik.
\end{abstract}

Keywords: Environmental sanitation, attitudes family, DHF

Copyright @ 2021 IIK STRADA Indonesia All right reserved. \section{International License.}

This is an open-acces article distributed under the terms of the Creative Commons Attribution-ShareAlike 4.0

\section{INTRODUCTION}

Dengue Hemorrhagic Fever (DHF) was still a public health problem in Indonesia. The disease caused by dengue virus is an infectious disease that enters human blood circulation through mosquito 
bites from the genus Aedes, for example Aedes aegypti or Aedes albopictus. (Kemenkes RI in Hadriyati, 2016). Indonesia is an area prone to DHF because the distribution of DHF is only found in tropical regions including Indonesia (Maulida, 2016).

WHO estimates that 2.5 billion people are at risk of DHF (Hadriyati, 2016). The incidence of DHF in East Java from January to the beginning of February 2019 contained 3,686 cases, while in Kediri there were 416 cases and 12 people died. Based on the results of a preliminary study at UPTD Public Health Centre Bendo on March 22, 2019 there were clients with dengue hemorrhagic fever (DHF) who suffered in January-March 2018 as many as 18 clients and data for the last 3 months (January-March) in 2019 as many as 30 clients who has dengue fever. The results of interviews conducted on 5 clients (respondents) who were stricken with dengue were known that 3 clients followed the advice of health workers such as doing 3M Plus (draining, closing, burying) and 2 clients (respondents) did not follow the advice of health workers.

Many factors affect the high incidence rate of DHF. An increase in dengue cases every year is associated with poor environmental sanitation, such as irregular drainage of the bathtub, not closing water reservoirs around the house or inside the house, lack of environmental hygiene so that there is garbage that can hold water and used as a place to lay eggs Aedes mosquitoes, not accustomed to bury used cans and others. This condition is exacerbated by the community's lack of understanding of DHF so that attitudes towards DHF events and prevention are still very negative so that community participation is very low. Aedes aegypti mosquitoes in breeding once lay eggs produce 100-102 eggs that survive for 6 months without water and hatch immediately after 2 days submerged in water. If eradication of mosquito breeding is not carried out, the development of Aedes aegypti mosquitoes will increase and can cause outbreaks.

Until now, especially in the rainy season the larva free rate $(A B J)$ is still low. Preliminary survey results in the working area of the Bendo Health Center in Kediri District in April 2019 of 53 houses inspected, are still not clean. This shows that the behavior of the community towards the prevention of dengue fever is still very low. These conditions allow the area is very risky for transmission of dengue disease.

The impact of poor environmental sanitation conditions is supported by a negative attitude towards the prevention of DHF, so the risk of DHF is still high. Therefore, every rainy season, the incidence of DHF is always high in various regions in Indonesia.

Given the potential of dengue disease to cause death, prevention efforts are needed. Prevention strategies through treatment are quite difficult considering there is no vaccine for prevention and there is no specific cure for healing (Depkes, 2010). On the other hand, patients with dengue fever who are still ill or carier have the potential to transmit it to others through the Aedes aegypti and Aedes albopictus mosquitoes. Prevention efforts can be made through breaking the chain of transmission. Therefore prevention of DHF can be done through eradicating mosquitoes or mosquito nests and mosquito larvae by means of $3 \mathrm{M}$ Plus (draining, closing, burying) mosquito breeding places (containers) plus the provision of fish (fishisation) in containers. The activity of eradicating mosquito nests or known as PSN is a real behavior of every individual to prevent dengue disease.

Given the background of the above problems, the researcher felt the need to conduct research by formulating in the writing title "the relationship of environmental sanitation and family attitudes with events of dengue hemorrhagic fever (DHF) in working areas UPTD Public Health Centre Bendo kediri district"

\section{MATERIALS AND METHODS}

Correlational analytic research design with cross sectional approach. The research was conducted from 17 July 2019 to 2 August 2019 in the Work Area of the UPTD Public Health Centre Bendo, Kediri Regency. The population of the entire community working area UPTD Public Health Centre Bendo District of Kediri diagnosed with DHF as many as 30 families with a sample of 30 respondents taken a total sampling. The independent variable is environmental sanitation and attitude, the dependent variable is dengue collected by questionnaire and checklist and analyzed by Mc Nemar test and Linear Regression. At $\mathrm{p}=<0.05$ then $\mathrm{H} 0$ is rejected and $\mathrm{p}=>0.05$ then $\mathrm{H} 0$ is accepted 


\section{RESULTS}

\section{Characteristics of Respondents}

Table 1 Characteristics of Respondents at UPTD Public Health Centre Bendo, Kediri Regency in 2019

\begin{tabular}{llll}
\hline No. & Karakteristik Responden & $\mathrm{f}$ & $\%$ \\
\hline Age & & & \\
1 & $<20$ years & 1 & 3.3 \\
2 & 20-35 years & 10 & 33.3 \\
3 & $>35$ uears & 19 & 63.3 \\
Education & & $\%$ \\
1 & Basic School & 2 & 6.7 \\
2 & First Middle School & 6 & 20.0 \\
3 & High Middle School & 19 & 63.3 \\
4 & University & 3 & 10.0 \\
Job & & & $\%$ \\
1 & Not Working & 4 & 13.3 \\
2 & Farners & 3 & 10.0 \\
3 & Private & 16 & 53.3 \\
4 & Civil Servants & 7 & 23.3 \\
\hline Total & & 30 & 100 \\
\hline
\end{tabular}

Based on table 1, it was known that most respondents> 35 years old are 19 respondents $(63.3 \%)$, most respondents have a high school education that is 19 respondents $(63.37 \%)$ and the majority of respondents work in private sectors, namely 16 respondents $(53.3 \%)$ of a total of 30 respondents.

\section{Environmental Sanitation in the Work Area of UPTD Public Health Centre Bendo, Kediri Regency in 2019}

Table 2 Environmental Sanitation in the Work Area of UPTD Public Health Centre Bendo, Kediri Regency in 2019

\begin{tabular}{llll}
\hline No & Environmental Sanitation & $\mathrm{f}$ & $\%$ \\
\hline 1 & Not Eligible & 28 & 93.3 \\
2 & Fulfilling Requirements & 2 & 6.7 \\
\hline Total & & 30 & 100
\end{tabular}

Based on table 2, it is known that almost all respondents have environmental sanitation that does not meet the requirements, namely as many as 28 respondents (93.3) out of a total of 30 respondents.

\section{Family Attitudes in the Work Area of UPTD Public Health Centre Bendo, Kediri Regency in 2019}

Table 3 Attitudes of Families in the Working Area of UPTD Public Health Centre Bendo District of Kediri in 2019

\begin{tabular}{llll}
\hline No & Family Attitudes & f & $\%$ \\
\hline 1 & Negative & 14 & 46.7 \\
2 & Positive & 16 & 53.3 \\
\hline Total & & 30 & 100 \\
\hline
\end{tabular}

Based on table 3, it is known that most of the respondents have a positive attitude in eradicating dengue fever as many as 16 respondents $(53.3 \%)$ out of a total of 30 respondents. 


\section{The Correlation of Environmental Sanitation with Occurrence of Dengue Fever in the Working Area of UPTD Public Health Centre Bendo, Kediri Regency in 2019}

Table 4 The Correlation of Environmental Sanitation with Incidence of Dengue Fever in the Working Area of UPTD Public Health Centre Bendo, Kediri Regency in 2019

\begin{tabular}{|c|c|c|c|c|c|c|c|}
\hline \multirow{3}{*}{ No } & \multirow{3}{*}{$\begin{array}{l}\text { Environmental } \\
\text { Sanitation }\end{array}$} & \multicolumn{4}{|c|}{ Incidence DHF } & \multirow{2}{*}{\multicolumn{2}{|c|}{-Total }} \\
\hline & & \multicolumn{2}{|c|}{ Occur } & \multicolumn{2}{|c|}{ Not happen } & & \\
\hline & & $\mathrm{F}$ & $\%$ & $\mathrm{~F}$ & $\%$ & $\mathrm{f}$ & $\%$ \\
\hline 1 & Not Eligible & 22 & 73.3 & 6 & 20.0 & 28 & $\begin{array}{l}93 . \\
3\end{array}$ \\
\hline 2 & $\begin{array}{l}\text { Fulfilling } \\
\text { Requirements }\end{array}$ & 0 & 0.0 & 2 & 6.7 & 2 & 6.7 \\
\hline \multicolumn{2}{|c|}{ Total } & 22 & 73.3 & 8 & 26.7 & 30 & 100 \\
\hline
\end{tabular}

Based on Figure 4, it can be seen that the sanitation conditions do not meet the requirements and there is a DHF occurrence, namely as many as 22 respondents $(73.3 \%)$.

Table 5 Mc Nemar Test Results of the Correlation of Environmental Sanitation with Incidence of DHF in the Work Area of UPTD Public Health Centre Bendo, Kediri Regency in 2019

\begin{tabular}{lcl}
\hline \multicolumn{1}{c}{ Variable } & p value \\
\hline Environmental & Sanitation & $-0,031$ \\
Incidence DHF & & \\
$\mathrm{N}=30$ & & \\
$\alpha=0,05$ & & \\
\hline
\end{tabular}

Based on table 5 , it is known that there is a correlation between environmental sanitation and the incidence of DHF in the UPTD Work Area of the Bendo Public Health Centre in Kediri Regency in 2019 (Mc Nemar $\mathrm{p}=0.031<0.05$ then Ho is rejected).

\section{Relationship between Family Attitudes and Incidence of Dengue Fever in the Working Area of UPTD Public Health Centre Bendo, Kediri Regency in 2019}

Table 6 The Corelation of Family Attitudes with Incidence of Dengue Fever in the Working Area of UPTD Public Health Centre Bendo, Kediri Regency in 2019

\begin{tabular}{|c|c|c|c|c|c|c|c|}
\hline \multirow{3}{*}{ No. } & \multirow{3}{*}{$\begin{array}{l}\text { Family } \\
\text { Attitudes }\end{array}$} & \multicolumn{4}{|c|}{ Incidence DHF } & \multirow{2}{*}{\multicolumn{2}{|c|}{-Total }} \\
\hline & & \multicolumn{2}{|c|}{ Occur } & \multicolumn{2}{|c|}{ Not Happen } & & \\
\hline & & $\mathrm{f}$ & $\%$ & $\mathrm{~F}$ & $\%$ & $\mathrm{f}$ & $\%$ \\
\hline 1 & Negative & 12 & 40.0 & 2 & 6.7 & 14 & 46.7 \\
\hline 2 & Positive & 10 & 33.3 & 6 & 20.0 & 16 & 53.3 \\
\hline Total & & 22 & 73.3 & 8 & 26.7 & 30 & 100 \\
\hline
\end{tabular}

Based on Figure 6, it can be seen that negative family attitudes of DHF occur by 12 respondents $(40 \%)$ while in positive family attitudes DHF occurs by 10 respondents $(33.3 \%)$. 
Table 7 Mc Nemar Test Results Correlation of Family Attitudes with Incidence of DHF in the Work Area of UPTD Public Health Centre in Bendo Kediri Regency in 2019

\begin{tabular}{ll}
\hline \multicolumn{1}{c}{ Variabel } & p value \\
\hline Family attitudes - Incidence DHF & 0.039 \\
$\mathrm{~N}=30$ & \\
$\alpha=0,05$ & \\
\hline
\end{tabular}

Based on table 7, it is known that there is a corelation between family attitudes and the incidence of DHF in the UPTD Work Area of the Bendo Public Health Centre in Kediri Regency in 2019 (Mc Nemar $p=0.039<0.05$ then Ho is rejected).

\section{Relationship of Environmental Sanitation and Family Attitudes with Occurrence of DHF in the Work Area of UPTD Public Health Centre Bendo, Kediri Regency in 2019}

Table 8 Linear Regression Test Results Relationship of Environmental Sanitation and Attitude of Family with Incidence of DHF in the Work Area of UPTD Public Health Centre Bendo District of

Kediri in 2019

\begin{tabular}{llll}
\hline Variable & Regression Coefficient $(\mathbf{B})$ & $\mathbf{t}$ & $\mathbf{p}$ \\
\hline Constants & 0.356 & 1.074 & 0.292 \\
Sanitation & 0.492 & 2.448 & 0.021 \\
Attitudes & 0.295 & 1.832 & 0.078 \\
$\mathrm{n}$ observation $=30$ & & & \\
$\mathrm{p}<0,005$ & & & \\
\hline
\end{tabular}

Based on table 8 above, it is known that there is no corelation between environmental sanitation and family attitudes with the incidence of DHF in the Working Area of UPTD Public Health Centre Bendo, Kediri Regency. ( $\mathrm{p}=0.292>0.005)$

\section{DISCUSSION}

1. The Corelation between Environmental Sanitation and Occurrence of Dengue Fever in the Working Area of UPTD Public Health Centre Bendo, Kediri Regency in 2019

Based on table 5, it is known that there is a corelation between environmental sanitation and the incidence of DHF in the UPTD Work Area of the Bendo Public Health Centre in Kediri Regency in 2019 (Mc Nemar $\mathrm{p}=0.031<0.05$ then Ho is rejected).

Sanitation according to the World Health Organization (WHO) is an effort that oversees several physical environmental factors that affect humans, especially those that affect its effects, damage physical development, health, and survival. Sanitation in English comes from the word sanitation which is interpreted as maintaining health. Ehler and Steel argued that sanitation is a surveillance effort aimed at environmental factors that can be a chain of disease transmission (Anwar, 2017). Many factors affect the high incidence rate of DHF. An increase in dengue cases every year is associated with poor environmental sanitation, such as irregular drainage of the bathtub, not closing water reservoirs around the house or inside the house, lack of environmental hygiene so that there is garbage that can hold water and used as a place to lay eggs Aedes mosquitoes, not accustomed to bury used cans and others. This condition is exacerbated by the community's lack of understanding of DHF so that attitudes towards DHF events and prevention are still very negative so that community participation is very low (Sofia in Hastuti, 2017).

The corelation between environmental sanitation and the incidence of DHF in the UPTD Work Area of the Bendo Health Center in Kediri in 2019 can be caused by various factors both from the characteristics of the respondents and environmental conditions. Based on the research results, it is known that almost all respondents have environmental conditions that do not meet the requirements. This can happen if someone does not pay attention to the sanitation conditions around his house. Dengue mosquitoes live in clean water, so if there is a pool of clean water around the environment it will become a breeding place.

Environmental conditions that do not meet the requirements are also influenced by factors such as respondents' age, education and occupation. Age factors of the majority of respondents aged> 35 years. In this age group, including the adult age group who should be able to think of 
the best things for the family, including prevention of dengue fever. However, at this age is a productive age where a person will be more focused on earning a living for his family so that he does not think about other things including environmental conditions that are factors for the breeding of DHF mosquitoes.

Based on work, most respondents work privately. Someone who works in a private sector is required to always be on time with the target work. This situation causes someone to have limited time when at home, especially to pay attention to the environmental sanitation conditions. They pay less attention to environmental sanitation, including the presence of a water reservoir which is a breeding place for dengue mosquitoes.

\section{The Corelation between Family Attitudes and Incidence of Dengue Fever in the Working Area of UPTD Public Health Centre Bendo, Kediri Regency in 2019}

Based on table 4.7, it is known that there is a corelation between family attitudes and the incidence of DHF in the UPTD Work Area of the Bendo Public Health Centre in Kediri Regency in 2019 (Mc Nemar $p=0.039<0.05$ then Ho is rejected).

A person's attitude towards an object is a feeling of favor or favor (favorable) or a feeling of not supporting (unfavorable) towards the object. Formulation according to Thrustone said that attitude is a degree of positive affect or negative effect that is associated with a psychological object. Attitudes are opinions, one's beliefs about objects or situations that are relatively fixed accompanied by certain feelings and provide a basis for that person to respond or behave in the particular way chosen. Attitude is a person's closed response to a particular stimulus or object that already involves the factor of opinion and emotion in question (happy-not happy, agreedisagree, good-not good, and so on). A person's attitude is influenced by personal experience, culture, influence of others, mass media, educational institutions and religious institutions as well as emotional factors in individuals.

The results showed a relationship between family attitudes and the incidence of DHF. This is due to the attitude that underlies a person's behavior including DHF eradication behavior. A positive attitude underlies the emergence of behavior to eradicate dengue mosquito nests. So in this case the eradication of DHF mosquitoes requires predisposition in the form of attitude. Attitude itself is a reaction or response that is still closed from someone to the stimulus or object. An attitude will not necessarily be realized in the form of action. Attitude becomes a real act, required supporting factors or conditions that allow, including conditions from within the individual itself.

\section{The Corelation of Environmental Sanitation and Family Attitudes with Incidence of Dengue} Fever in the Work Area of UPTD Public Health Centre Bendo, Kediri Regency in 2019

Based on table 4.8, it is known that there is no relationship between environmental sanitation and family attitudes with the incidence of DHF in the Bendo UPTD Work Area in Kediri District in 2019 (Linear Regression $p=0.110>0.05$ then Ho is accepted).

The results showed no relationship between environmental sanitation and family attitudes with the incidence of DHF. In theory, the breeding of DHF mosquitoes is strongly influenced by environmental factors. The environment in question is primarily a means of clean water and puddles of clean water in the home environment. Dengue mosquito breeding is clean water if there is a puddle of clean water that is not drained will be a very good place for mosquito breeding. While the attitude is not related to the incidence of DHF because the attitude is not yet a real action that supports the eradication of dengue fever mosquitoes. Attitude only underlies the formation of a behavior. If you have a good attitude will form good behavior to prevent dengue fever. The behavior in question includes dislike hanging dirty clothes in the room, draining clean water tubs.

\section{CONCLUSION}

There is a relationship between environmental sanitation and the incidence of dengue fever in the Work Area of the UPTD Public Health Centre Bendo, Kediri Regency in 2019 (McNemar p = $0.031<0.05$, so Ho is rejected). There is a relationship between family attitudes and the incidence of dengue fever in the Work Area of the UPTD Public Health Centre Bendo, Kediri Regency in 2019 (Mc Nemar $\mathrm{p}=0.039<0.05$, so Ho is rejected). There is no relationship between environmental sanitation and family attitudes with the incidence of dengue fever in the Work Area of the UPTD Public Health Centre Bendo, Kediri Regency in 2019 (linear regression $p=0.110$ > 0.05 , so Ho is accepted). 


\section{SUGGESTIONS}

It is recommended that the community be more concerned with environmental sanitation to reduce the occurrence of dengue fever by routinely eradicating dengue nests as a manifestation of the movement of one house 1 cadre of jumantik. It is recommended that the village government support the movement of 1 house 1 cadre of jumantik routinely giving out information every time there is a meeting with the community. It is recommended that the Public Health Centre routinely conduct training and monitoring of the movement of one jumantik cadre 1 house by conducting field visits to conduct periodic larvae checks so that it can be used as an example for the community. It is recommended that further researchers utilize the results of this study as one of the study material or as relevant research in conducting research related to the relationship of environmental sanitation and attitudes to the incidence of DHF.

\section{ACKNOWLEDGMENTS}

The author would like to thank the research funder, namely STIKes Bhakti Mulia, and thank the respondents for the valuable information and awareness to participate in this research.

\section{CONFLICTS OF INTEREST:}

The authors state that they have no conflict of interest

\section{REFERENCES}

Achmadi. (2010). Buletin Jendela Epidemiologi (Manajemen Demam Berdarah Berbasis Wilayah. Jakarta : Kemenkes RI

Anwar F, Aryani D. (2017). Sanitasi Makanan dan Minuman Pada Institusi Pendidikan Tenaga Sanitasi, Pusat Pendidikan Tenaga Sanitasi. Jakarta : Pusat Pendidikan Tenaga Kesehatan Depkes RI. h. 6.

Azwar, S. (2016). Sikap Manuasia Teori dan Pengukurannya. Jakarta: Rineka Cipta.

Bahtiar. (2016). Kondisi Sanitasi Lingkungan Kapal penumpang PT. Pelni KM. Lambelu, Makassar, Sulawesi Selatan, h. 27.

Depkes RI. (2015). Pedoman Teknis Pelaksanaan Program Penyehatan Lingkungan Pemukiman,. Jakarta : Ditjen PPM \& PLP, h. 55.

Depkes RI. (2010). Waspadai Demam Berdarah., Info dalam http/www. depkes.go.id.

Ditjen P2P-PL. (2016). Data Program Pemberantasan Penyakit Demam Berdarah Dengue. Jakarta : Kementerian Kesehatan RI.

Hadriyati A, Marisdayana R, (2016). Hubungan sanitasi Lingkungan Dan Tindakan 3M Plus Terhadap Kejadian DBD. Jurnal Endurance Vol 1No1.DOI: http://dx.doi.org/10.22216/jen.vlil.601

Indra, Juliansyah E. (2017). Hygiene Sanitasi Rumahdengan Kejadian Demam Berdarah Dengue (Sanitation Hygiene Home with Events Dengue). Sekolah Tinggi Ilmu Kesehatan Kapuas Raya Sintang. Jurnal DBD. Vol.3 Nomor 2 Januari Tahun 2017 ISSN : 2087-4995.

Isnaini. (2014). Tinjauan Pustaka tentang Sanitasi Lingkungan. http://eprints.walisongo.ac.id

Keputusan Menteri Kesehatan Republik Indonesia nomor :965/MENKES /SK/XI/1992.

Maulida I, Sakti Prastiwi R, Harlyn Hapsari L. (2016). Analisis Hubungan Karakteristik Kepala Keluarga Dengan Perilaku Pencegahan Demam Berdarah di Pakijangan Brebes. Jurnal Ilmiah Rekam Medis dan informatika kesehatan Vol 6 No 1 ISSN : 2086-2628.

Nazir, M. (2017). Metode Penelitian Bogor: Ghalia Indonesia Salemba Medika.

Nursalam. (2017). Metodologi Penelitian Ilmu Keperawatan: Pendekatan Praktis. Jakarta: Salemba Medika.

Peraturan Menteri Kesehatan Republik Indonesia Nomor 3 Tahun 2014 tentang Sanitasi Total Berbasis Masyarakat

Rahayu Y, Budi IS, Yeni. (2017). Analisis Pertisipasi Kader Jumantik Dalam Upaya penanggulangan Demam Berdarah Dengue (DBD) Di Wilayah Kerja Public Health Centre Indralaya.Jurnal Ilmu Kesehatan Masyarakat Vol. 8 No 3 ISSN :2086-6380. https//doi.org/10.26553/jikm.2017.8. 3 200-2017.

Purwanto S, Sudiharjo, Ristanto B. (2011). Penyediaan Air Bersih, Proyek Pengembangan Pendidikan Tenaga Sanitasi Pusat Pendidikan dan Latihan Pegawai,. Jakarta : Departemen Kesehatan RI.

Suroso, T. (2017). Perkembangan Demam Berdarah Dengue di Indonesia, Majalah Kesehatan. 
Syamsul, Musdalifah. (2016). Hubungan Faktor Lingkungan Dengan Kejadian Demam Berdarah Dengue di Kabupaten Maros Sulawesi Selatan. UNM Environmental Journals. Vol. 1 No. 3 Agustus 2018 Hal. 82 - 85 p-ISSN: 2598-6090 dan e-ISSN: 2599-2902 